\title{
Choralne dyslokacje
}

Maciej Topolski

TEKSTY DRUGIE 2018, NR 5, S. 309-319

DOI: 10.18318/td.2018.5.18

W 1997 roku ukazała się książka Chora L Works' stanowiąca wynik współpracy Jacques’a Derridy i Petera Eisenmana. Propozycja współpracy padła ze strony szwajcarskiego architekta Bernarda Tschumiego, który zaprosił obu do pracy nad projektem jednego z ogrodów położonych wzdłuż promenady kinematycznej będącej częścią Parc de la Villette w Paryżu. Ta choralna książka - przez choralność rozumiem „wyłącznie” to, co dotyczy chory - będąca wynikiem zderzenia filozoficzno- architektonicznego składa się z fragmentów Timajosa, transkrypcji rozmów, szkiców architektonicznych, listów etc. W rozmowie otwierającej książkę Derrida mówi, że w czasie, kiedy otrzymał propozycję, był w trakcie pisania tekstu o chora, enigmatycznym ustępie platońskiego Timajosa. Tak francuski filozof streszcza wspomniany tekst:

Platon rozważa pewne miejsce. Nazwą tego niezwykle wyjątkowego miejsca jest chora. W grece

1 J. Derrida, P. Eisenman Chora L Works, ed. by J. Kipnis, T. Leeser, The Monacelli Press, New York 1997.
Maciej Topolski -

mgr, doktorant na Wydziale Polonistyki Uniwersytetu Jagiellońskiego.

Współpracuje z serwisami taniecpolska.pl i Opcje 1:1. Redaktor niedoczytania.pl w latach 2009-2011. Laureat I nagrody w kategorii esej w Konkursie im. Stanisława Dobrzyckiego (2013). Przygotował wybór wierszy Adama Wiedemanna Domy schadzek (2013). Opublikował tom wierszy na koniec idq (2017) Kontakt: matopolski@gmail.com 
chora jest „miejscem” i posiada wiele znaczeń: miejsce jako takie, siedziba, habitat, miejscowość, w której żyjemy, kraj. Chora wiąże się odstąpieniem miejsca [interval]; to jest to, co otwiera się, żeby "dać" miejsce rzeczom, albo kiedy otwiera się coś, żeby rzeczy mogły zająć miejsce [take place]. Jeśli miałbym podsumować $\mathrm{w}$ wielkim skrócie kontekst, w którym te trzy czy cztery strony omawiające chora się pojawiają, powiedziałbym, że nie jest to coś po prostu platońskiego. Chora jest czymś, czego Platon nie może bezpośrednio uznać za swoją myśl. W Timajosie Platon tłumaczy narodziny kosmosu. Kosmos, jak wiecie, znaczy porządek [arrangement]: świat jako uporządkowany, zorganizowany [ale także „upiększony" - przyp. M.T.].Ten motyw rozwija następująco: architekt-Demiurg, który zrodził nasz widzialny świat, przygląda się paradoksowi - formom, które są wieczne; ideom będącym wiecznymi bytami. Te formy poprzedzają go, one sa przed czasem [są anachroniczne - przyp. M.T.], a kiedy się im przygląda, nadaje tym formom zmysłowy opis, stają się zmysłowe [sensible, czyli „racjonalne”, „postrzegalne”, ale i „poważne" - przyp. M.T.]. Takie jest pochodzenie naszego zmysłowego świata; jest to kopia, reprezentacja tych wiecznych bytów. Tak więc mamy dwa rodzaje bytów: eidos, który jest wieczny i niezmienny, i stający się świat, zmysłowe. Dwa rodzaje bytów, jeden kopią drugiego. Teraz Platon mówi - i to jest bardzo dziwne tutaj - istnieje coś innego jeszcze, trzeci element, triton genos. Ten trzeci rodzaj, albo genos [co w grece oznacza „pochodzenie”, „rasę" - przyp. M.T.], nie jest ani wiecznym eidosem, ani zmysłową kopią, ale miejscem, w którym te wszystkie rodzaje [types] są wpisane, czyli chora. Omawiając chora, Platon posługuje się tym, co pokolenia filozofów nazywały „metaforami”, tylko że według mnie to nie są metafory. Matka, matryca lub mamka. Można porównać, mówi on, paradygmat z ojcem, zmysłowy świat z dzieckiem lub niemowlęciem, zaś chora, to miejsce inskrypcji, z matką lub mamką. Ale to są tylko metafory, ponieważ zostały one zapożyczone ze zmysłowego świata. Tak więc chora nie jest matką, ani mamką, która pielęgnuje niemowlęta. Chora nie daje się zredukować do tego wszystkiego, czemu filozofia Platona zawdzięcza swoją koherencję. Jest to hybrydyczny byt; rodzaj bytu, który możemy pomyśleć wyłącznie we śnie. Chora nie jest po prostu pustką, chociaż wygląda jak gdyby była pustką, i nie jest czasowa w tym sensie, w jakim czasowy jest zmysłowy świat. $^{2}$ 
Chora, podług Derridy, użycza miejsca, obdarowuje rzeczy miejscem, żeby mogły stać się rzeczywiste. Sama pozostaje jednak tym, co może być pomyślane tylko jako sen. Sen, jak powie Freud, ,jest niejako in a c z ej wy c e n tro w a ny"', co oznacza, że nie ma swojego miejsca albo że miejscem snu jest zdecentralizowana inność, która „nieustannie działa i podróżuje. Dotyka wszystkiego. Narzuca paradoksalne prawo, a raczej przymus, który jest prawem nietrwałości i braku reguł" ". Zresztą sięgnijmy do samego Platona i tam poszukajmy snu rozumianego jako dyslokacja, przechodzenie lub przemieszczenie.

W Charmidesie Sokrates rozmawia z Krytiaszem, snując przed nim marzenie o racjonalizacji życia, o rodzie ludzkim mającym „postępować i żyć zgodnie z nauką": „Więc posłuchaj, powiadam, mojego snu - wszystko jedno, czy przeszedł przez rogową bramę, czy też przez bramę z kości słoniowej"5. Sokrates śni o racjonalności, której pochodzenie, genos, nie jest znowuż tak istotne, a jednak. Czym jest brama rogowa, a czym ta z kości słoniowej? Fragment z Platona odnosi się do Pieśni XIX z Odysei Homera, gdzie czytamy:

Bo, jak mówią, do krain sennych wchód dwojaki:

Bramą z kości słoniowej i bramą rogową.

Więc sny z pierwszej idące plotą to i owo,

A ich wróżby kłamliwe zawsze nas zawodzą;

Za to sny, co przez bramę rogową przechodzą, Iszczą się i nie mylą ludzi, co śnią nimi. ${ }^{6}$

Jest to wielce wątpliwa teoria snów. Stworzyła ją Penelopa na podstawie gry słownej. Sny, które przechodzą przez bramę rogową (kéras - róg), sprawdzają się (krájnejn - spełniać), zaś te, które przekroczyły bramę z kości słoniowej (eléfas - kość słoniowa), zwodzą nas (elefájresthaj - łudzić), nie spełniając się wcale. Sokrates u Platona nie przejmuje się pochodzeniem snu o racjonalizacji, nie interesuje go miejsce, przez które ten sen przechodzi, miejsce

3 S. Freud Objaśnianie marzeń sennych, przeł. R. Reszke, KR, Warszawa 1996, s. 246.

4 G. Didi-Huberman Przed obrazem. Pytania o cele historii sztuki, przeł. B. Brzezicka, słowo/obraz terytoria, Gdańsk 2011, s. 101.

5 Platon Charmides, w: tegoż Dialogi, przeł., wstęp i objaśn. W. Witwicki, Antyk, Kęty 1999, t. 1, s. 78.

6 Homer Odyseja (wybór), przeł. L. Siemieński, wstęp Z. Abramowiczówna, oprac. J. Łanowski, Ossolineum, Wrocław 1975, s. 357. 
zarazem łudzące (niepoważne) i prawdo-podobne (poważne). A mimo to wspomina o nim, przywołuje wpisaną w bramę dwojakość pochodzenia. Powróćmy do Penelopy, która jest, jak stwierdzi Anne Carson w eseju Every Exit Is an Entrance (A Praise of Sleep), ,"mistrzynią snów"7:

W trakcie opowieści układa się do snu tuzin razy, wielokrotnie zapada w sen zesłany jej przez bogów, zaznaje snów wymownych i spełniających się, wreszcie wypracowuje własną teorię czytania snów. Co więcej, Homer ujawnia dość wcześnie, bo już w Księdze IV, że sen stanowi najbardziej doniosłą umowę wiążącą ją z mężem. [...] Sen pracuje dla Penelopy.

Za sprawą tej pracy snu Penelopa będzie mogła rozpoznać w obcym przybyszu swojego Odyseusza. Jak to rozpoznanie się dokona? Nie inaczej jak za sprawą miejsca. Odyseusz powraca do domu w przebraniu. Penelopa chcąc ujawnić jego tożsamość, musi przedsięwziąć, jak określi to Carson, „łóżkowy fortel". Pytanie, które zadaje Penelopa, jest na wskroś praktyczne: kto gdzie śpi? Jest to jednocześnie pytanie o miejsce („gdzie”), jak i o tożsamość („kto”). Penelopa chce podjąć gościa w małżeńskim łożu, które mogłoby w tym celu zostać przeniesione do korytarza. Odyseusz oburza się na taką wiadomość, gdyż tylko on wie, że to łoże, mające swoje miejsce w komnacie, pośrodku ich domostwa, powstało dwadzieścia lat temu z oliwnego drzewa dzięki pracy jego rąk. On tylko wie, że on je zrobił. Penelopa każe Euryklei, mamce Odyseusza, pościelić łoże.

Nie w tej, którą budował, sypialnej komorze,

Ino wynieś je stamtąd, naściel skór baranich,

[...]

Lecz Odys przerwał gniewny: O, jakże mię rani,

Kobieto, twoja mowa! I któż to przestawił

Moje łóżko? Kto ruszył? Tego by nie sprawił

I najświadomszy rzeczy; chyba moce boże

Mogłyby cudem ruszyć z miejsca moje łoże,

Ale nikt żywy, nawet z siłą nadzwyczajną,

7 A. Carson Every Exit Is an Entrance (A Praise of Sleep), w: tejże Decreation. Poetry, Essays, Opera, Vintage Books, New York 2005.

8 Tamże, s. 29. 
Gdyż jedną w nim przeszkodę zamknąłem był tajną, Kiedym sam wyciosywał to łoże przedziwne. ${ }^{9}$

Następnie Odyseusz opisuje sposób wykonania miejsca, by już na samym końcu raz jeszcze zadać pytanie, czy „moje łoże stoi tam, gdzie stało zawdy / Czy też je kto poruszył, gwoli przeniesienia / Odrąbał pniak oliwny spodem, od korzenia?"10. To, czego Odyseusz obawia się najbardziej, związane jest z dyslokacją. Rzecz osobliwa, jeśli weźmiemy pod uwagę jego wieloletnią podróż.

Maria Theodorou w artykule Space as Experience: "Chore/Choros" ${ }^{\prime 11}$, dokonując szczegółowej analizy homeryckich tekstów, wykazuje, że chora nie zawsze oznaczała neutralny pojemnik albo naczynie, jak to przedstawia Platon. U Homera chora (przestrzeń) już sama ze swojej natury jest zdyslokowana Poza tym stosuje się u niego żeńskie określenie chorale oraz męskie choros. Żeńskie chore związane jest z doświadczaniem rzeczy (np. łóżko i Penelopa), natomiast męskie choros - doświadczaniem wydarzeń (np. przesunięcie łóżka Odyseusza). Kształtowanie miejsca zależne jest od ciała, które zarazem nabiera tożsamości w zależności od miejsca. Dlatego też Odyseusz odkrywa swoją tożsamość w momencie, gdy Penelopa zamierza ruszyć z miejsca jego miejsce, tzn. dyslokuje to, co określa jego tożsamość.

Cezary Wąs, omawiając spotkanie Derridy i Eisenmana, stwierdza:

Pochodzenie miejsca jest ulokowane w ciele, a relacje między nimi są głęboko wewnętrzne, rzec można - trzewiowe. Takie miejsce nie wymaga zewnętrznego pojemnika. Nie jest też trwałe. Podobnie w przypadku choros wytwarzanego przez wydarzenie: trwa ono tak długo, jak owo wydarzenie, chociaż czas jest wewnętrzny dla wydarzenia. [...] Chore/choros określają doświadczenia, a ponieważ doświadczenia są pojedyncze, nie mogą być traktowane jako pojęcia. Ich aktualne rozumienie zależne jest od stopnia tolerancji wobec pojedynczości, odmienności i ulotności. Zamieniają się w pojęcia wraz ze strachem przed nieprzewidywalnością czegokolwiek, co nie trwa, również przed myśleniem. ${ }^{12}$

9 Homer Odyseja, s. 413.

Tamże, s. 414.

M. Theodorou Space as Experience. "Chore/Choros", "AA Files” 1997 No. 34, s. 45-55.

12

C. Wąs Architektura, która naśladuje niemą filozofię. Peter Eisenman a dekonstrukcja. Część III, "Quart" 2012 No. 3 (25), s. 78-79. 
Podejmijmy ten trop trzewiowy. Derrida stwierdza, że chora „nie jest” ani matką, ani żywicielką, ani nawet kobietą. Triton genos, czyli trzeci rodzaj, nie będąc też genosem, stanowi jednostkę unikatową. „Nie należy do «rasy kobiet» (genos gynaikon)"13. Po tym fragmencie Derrida odwołuje się do książki Nicole Loraux Les enfants d'Athéna. Nas będzie interesować inna książka Loraux, tj. Façons tragiques de tuer une femme ${ }^{14}$, której ostatni rozdział poświęcony jest autopsji ciała kobiety - ciała, które zostało ukonstytuowane przez tragiczną wyobraźnię Greków, wyobraźnię, w której wygrywając, od razu przegrywasz ${ }^{15}$.

Śmierć w teatrze greckim zadawana jest kobiecie w szyję, „miejsce piękne i równie wrażliwe - tak na sznur, jak i na nóż", jak stwierdzi Anne Carson w eseju Chez l'Oxymoron ${ }^{16}$. Ciało mężczyzny jest bardziej zróżnicowane pod względem podatności na śmierć. Jego delikatne miejsca to bok, żołądek, pierś, płuca czy wątroba. Z tego powodu Dejanira w Trachinkach Sofoklesa swój bok „żelazem dwusiecznem / Przebiła do wątroby i błony osierdzia"17, przywłaszczając tym samym broń mężczyzny, typ samobójstwa (większość kobiet $\mathrm{w}$ tragedii antycznej zawisa bowiem na stryczku) oraz anatomię śmierci mężczyzny. Cios Dejaniry jest złożony, gdyż wbijając ostrze poniżej wątroby, otwiera lewą stronę ciała:

tu zaczyna się problem. Żeby dźgnąć się poniżej wątroby, Dejanira odsłania lewą, nie prawą stronę ciała, jak moglibyśmy się spodziewać, nawet gdyby nasza wiedza na temat anatomii była skąpa. [...] ta nieprawidłowość jest brzemienna w znaczenie [pregnant with meaning]; wystawiając swoją lewą stronę, żona Heraklesa pozostawia obnażoną żeńską stronę. To tekstualna pułapka, sprzeczność umyślnie przedstawiona dla podkreślenia tego, że śmierć kobiety, choć zaaranżowana w najbardziej męski sposób, nadal podlega prawom jej płci. [...] Dejanira rzeczywiście ginie od ciosu zadanego poniżej wątroby $i$ w lewy bok, jako zakochana kobieta, która pragnie in extremis przyjąć wartości uznawane przez żołnierski

J. Derrida Chora, przeł. M. Gołębiewska, KR, Warszawa 1999, s. 89.

N. Loraux Façons tragiques de tuer une femme, Hachette, Paris 1985. Korzystam z przekładu na język angielski - tejże Tragic Ways of Killing Women, Harvard University Press, Cambridge 1991. Zob. tamże, s. 49.

A. Carson Chez l'Oxymoron, "Grand Street" 1988 No. 4, s. 168-174.

Sofokles Tragedie, przeł. K. Morawski, oprac. i wstęp Z. Kubiak, PIW, Warszawa 1969. 
świat. Możemy założyć, że męskie ciało, nawet gdy widziane przez niejednoznaczność tragedii, nie ujawnia takich niezgodności. ${ }^{18}$

Tak tworzy się ten brzemienny w znaczenia oksymoroniczny triton genos, „męska kobieta”, która przebija sobie bok, wątrobę, czyli „siedzibę namiętności” (jak to określi Horacy) lub „dom życia” (jak powie w De Natura Deorum Cyceron) ${ }^{19}$. Według wyobraźni greckiej, jak stwierdzi Jean-Paul Vernant (patronujący zresztą Chorze Derridy), kobieta wyznawała niezmienne prawo serca, mężczyzna natomiast ucieleśniał „niewyczerpaną ruchliwość Hermesa”. Dejanira wbija miecz w sam środek wyobraźni greckiej i odwraca ją na nice.

Dyslokacja w ciele Dejaniry odpowiada temu, jak postrzegał tworzenie się chora Platon, tzn. przez oddzielenie myślenia od doświadczenia. Chora zaznacza czy nawet produkuje oddzielenie między myśleniem i doświadczeniem. Jest to zgodne z teorią idei jako dziedziny oddzielonej od doświadczenia, a mimo to potrzebującej koncepcji przestrzeni (domu, siedziby) jako trwałego, biernego naczynia, w którym rzeczy się kształtują. W interpretacji Derridy chora wiąże się z zagłębieniem się w sugestię, jaką wysunął swego czasu Heidegger. Twierdził on, że koncepcja przestrzeni wynika bezpośrednio nie jako konieczna konsekwencja ludzkiego doświadczenia, ale jako konsekwencja platońskiej filozofii.

Dyslokacja w ciele Dejaniry nie polega więc wyłącznie na przeniesieniu wątroby z jednego miejsca ciała w drugie lub odwróceniu męskiej i kobiecej strony ciała w wyobraźni starożytnych Greków. Chodzi tu przede wszystkim o aporetyczną sytuację, kiedy śmiercionośny cios otwiera „dom życia”, tak że ani śmierć, ani życie, nie mogąc znaleźć swojego miejsca, splatają się w niemożliwości spełnienia. Dejanira zdobywa władzę nad sobą - ale też nad widzami tragedii antycznej - w chwili, kiedy całą władzę odbiera sobie wraz z życiem.

Śmierć kobiety, tak jak ją widzimy odgrywaną w klasycznej tragedii, jest retorycznym związkiem męskich i żeńskich idiomów, połączonych pod przymusem w nieprawidłowe kształty i nieprawdopodobne myśli: przyjemne do tego stopnia, że pozostają nie do pomyślenia nawet wówczas, gdy dają się ogarnąć myślą - bezkształtne, gdy nabierają kształtu. Balansowanie między męskim i żeńskim, mające miejsce prawdopodobnie

18 N. Loraux Tragic Ways of Killing Women, s. 55-56.

Zob. C.T. Lewis, C. Short A Latin Dictionary, Clarendon Press, Oxford 1879, s. 1018 [hasło: jecur]. 
tylko podczas oglądania tragedii greckiej, jest przyjemnością, która dryfuje w umyśle niby zapach - zapach zimnego potu, kiedy aktor unosi ku twarzy kobiecą maskę. ${ }^{20}$

Śmierć kobiety dokonywała się w tragedii greckiej w przebraniu męskim i za zamkniętymi drzwiami, poza sceną. Dopiero po tym wydarzeniu posłaniec w pięknej przemowie przedstawiał, co zaszło. Mamy tu do czynienia z dwoma paradoksami. Pierwszy dotyczy miejsca w przestrzeni sceny, drugi wiąże się z mową. Zauważmy, że kobieta umiera poza sceną: w tym sensie - śmierć, kobieta - jest obsceniczna, dosłownie sprzeciwia się (ob-) ulokowaniu w przedstawieniu ${ }^{21}$.Śmierć kobiety,jak chora, przeciwstawia sięzatem zarówno czasowi (wskazówka zegara porusza się w odwrotnym kierunku), jak i miejscu (jako nieprzyzwoita, nieodpowiednia, zdyslokowana jest poza reprezentacją). Dopiero przywdzianie męskiego ubioru, wchłonięcie męskiej anatomii, zapoznanie się z męskim głosem i męską bronią pozwala przedstawić śmierć kobiety na scenie. Ujmując rzecz w skrócie, utrata życia i kobiecości umożliwia zajęcie miejsca w reprezentacji. Tylko tak Dejanira odnosi zwycięstwo, i tym samym zdobywa głos przez zamillknięcie. Wystawia wykluczenie. Mówi brakiem języka.

Jeśli zmysłowy świat porównamy, jak chciał Platon, do dziecka lub niemowlęcia, to należy przy tym pamiętać, że niemowlę przede wszystkim nie mówi, jest cielesnym brakiem języka. Infantissimes, tak nazywał Cyceron niemowlęta, którym to mamki właśnie opowiadały bajki (fabulae) - żeby "chłopiec niemowa" (puer infant) zaczął mówić (fari), żeby mógł zostać fans, fabulor albo fabulosus ${ }^{22}$. To właśnie mamki, do których porównuje Platon chorę, opowiadają bajki, żeby dziecko mogło mówić. W tym sensie umożliwiają mówienie (nadawanie znaczeń), dają miejsce dziecku w języku. Niejako otwierają bramę z marzeń sennych, w której przejściu konfabuluje się i/lub mówi prawdę. (Po prawdzie to Eurykleja, mamka Odyseusza, miała przygotować mu miejsce do snu, dać je w geście przemieszczenia) ${ }^{23}$. Dlatego też mowa ich nie jest, jak stwierdzi Derrida:

20 A. Carson Chez l'Oxymoron, s. 169.

21

W botanice prefiksu ob-używa się na określenie czegoś o odwróconym kształcie, dla przykładu rośliny wijącej się we wzrastaniu w kierunku przeciwnym do ruchu wskazówek zegara. Za P. Quignard Albucjusz, przeł. T. Komendant, Czytelnik, Warszawa 2002, s. 174-175. tiglio Hands know the truth. Touch in Euryclea's recognition of Odysseus, w: Touch and the Ancient Senses, ed. by A. Purves, Routledge, London-New York 2018, s. 21-33. 
ani mową tych, których dotyczy, ani tych, do których się zwraca. Wydarza się w trzecim rodzaju i w neutralnej przestrzeni miejsca bez miejsca, miejsca, gdzie wszystko się zaznacza, ale które „w sobie samym" nie jest zaznaczone. ${ }^{24}$

Na zakończenie tego tekstu zatrzymajmy się tam, gdzie dokonuje się naznaczenie. Słowo „naznaczenie” Ewa Kobylińska wywodzi z opisu funkcjonowania aparatu psychicznego, którego dokonał Freud, używając do tego „języka «sensu» i języka «siły», czy jak kto woli, energii" ${ }^{25}$. Posłużył się on w tym przypadku określeniami: nacisk (Drück), wrażenie w sensie impresji (Eindrück), odcisk (Ahdrück), stłumienie (Unterdrückung). Zdaniem Derridy sens i siła - szyfr i energetyka - są tym samym. To w wyniku zróżnicowania sił powstaje sens. Naznaczenie oddaje jednoczesność działania siły i znaczenia (sensu). Kobylińska zadaje następnie pytanie, „jak przechowywać naznaczenia w pamięci, lecz także - jak osłabić ich pierwotną, jakże często traumatyzującą siłę?". Odwołuje się do opisu mechanizmu pracy marzenia sennego polegającego na zagęszczeniu i przemieszczeniu, a według Derridy - uprzestrzennieniu i uczasowieniu:

Brzmi to skomplikowanie, ale opiera się na prostym pomyśle. Nieprzyjemne treści nie są po prostu odrzucane, ale rozdzielane i wysyłane do różnych „pomieszczeń”. Uprzestrzennienie rozdziela miejsca inskrypcji, szyfruje je i przemieszcza, powtarza i tłumi, osłabiając w ten sposób gwałtowność naszych pragnień i naszego bólu. Uczasowienie to wybór drogi okrężnej, przesunięcie na później, na kiedy indziej, zerwanie ciągłości żywej pamięci, aby przechować ślady. [...] Znaczenia powstają przez odniesienie do wcześniejszych i do późniejszych znaczeń. Stwarza to czasowy i przestrzenny interwał, przerwę dzięki której, jak pisze Heinz Kimmerle: „teraźniejszość różni się od samej siebie”. ${ }^{26}$

Interesuje mnie ten interwał, czyli odstęp w czasie lub odległość w przestrzeni. Tym samym słowem - interval - posługuje się Derrida, kiedy opisuje sposób, w jaki chora odstępuje miejsce: otwarcie, dzięki któremu rzeczy

24 J. Derrida Chora, s. 55 .

E. Kobylińska Czarodziejski blok i szpulka. Psychoanaliza i nowoczesność, „Teksty Drugie” 2007 $\mathrm{nr} 1 / 2$, s. 22. 
mogą zająć miejsce. Zwróćmy jeszcze uwagę, że określa on chorę jako miejsce inskrypcji, czyli wpisania lub zapisania. W każdym z trzech omówionych przykładów - Sokrates, Odyseusz, Dejanira - mamy do czynienia z miejscem zapisania: brama rogowa decyduje o snach, łóżko ujawnia tożsamość, scena tragedii greckiej pozwala na śmierć kobiety. W tym miejscu decyzji - jaki to sen? kim jest przybysz? czy wątroba znajduje się po lewej stronie ciała? - w którym rzeczy zajmują miejsce, są one zarazem dyslokowane pod wpływem siły (przymusu, a nawet przemocy). Wydaje się, że właśnie w tym interwale dokonuje się coś szczególnego, mianowicie nadawane jest pod wpływem siły znaczenie (jest zapisywane, naznaczane, a nawet wdrukowywane $^{27}$ ), a zarazem jest ono przesuwane (na kiedy indziej) lub przemieszczane (gdzie indziej). Warto przypomnieć, że w geologii dyslokacją określa się przemieszczenie warstw skalnych wywołane ruchami skorupy ziemskiej, ale również samą strukturę powstałą w wyniku takiego przemieszczenia. Choralna dyslokacja tworzyłaby zatem nową strukturę znaczenia: takiego znaczenia, które jest tutaj, odciśnięte, do wymówienia i takiego, które jest gdzie indziej, wygięte odciśnięciem, uchylające się od wymówienia. Znaczenia przechodzącego bramą rogową i bramą z kości słoniowej. Prawdo-podobnego i łudzącego.

27 W języku niemieckim istnieją dwa słowa określające pracę, jaką wykonuje drukarska matryca odbijająca się lub odciskająca w/na papierze: drucken (drukować) oraz drücken (naciskać, przyduszać, ugniatać). 


\section{Abstract}

\section{Maciej Topolski}

JAGIELLONIAN UNIVERSITY (CRACOW)

Choral Dislocations

Topolski explores the kind of"places" in ancient literature that would be close to Derrida's interpretation of khora. Examples from Homer's Odyssey and Greek drama offer possibilities for such readings from the irrational (dreaming) character of khora through gender distinctions related to experiencing a space, to the oxymoronic suicide of women in Greek theatre.

\section{Keywords}

khora, Derrida, space, Carson, Greek tragedy, corporeality 